\title{
Ausferrite Flake Graphite Cast Iron at the Thermal Fatigue
}

\author{
Břetislav Skrbek ${ }^{1}$, Jiří Hampl ${ }^{2}$ \\ ${ }^{1}$ KMT SF TU Liberec, Studentská 2, 461 17, Liberec, E-mail: bretislav.skrbek@tul.cz \\ ${ }^{2}$ VŠB TU FMME, 17. listopadu 15, 70833 Ostrava Poruba, E-mail: jiri.hampl@vsb.cz,
}

The automotive brake (clutch) disks are produced almost exclusively from flake graphite cast iron. These disks must fullfil a variety of strictly controlled parameters - high wear resistance, hardness, resistance against thermal fatigue and good thermal conductivity. The microstructure is created by the IA graphite in pearlite matrix. The isothermal hardening to ausferrite structure (AGI) was made in order to improve standard flake graphite cast iron properties. New methods and procedures of non-destructive structuroscopy, magnetoinductive, ultrasound and magnetic spot methods were used to compare material properties of flake graphite cast iron and ADI. By these methods, elasticity modulus, strength and hardness were evaluated. The resistance against thermal fatigue was evaluated by the Eichelberg factor. In this contribution, Material parameters of standard flake graphite cast iron and AGI are compared. The heat treatment of brake disk matrix from AGI can considerably improve their material parameters, especially durability.

Keywords: Non-destructive testing, thermal fatigue, brake disks, austempered cast irons

\section{References}

[1] EN 1564 - 2012. Founding - Ausferitic spheroidal graphite cast iron. Standard.

[2] ̌̌EZÁČ, Z. (2007). Pevnost přepážek válců motoru z různých období. M.Sc. thesis, TU of Liberec.

[3] SKRBEK, B. NOSEK, V. (2005). Materiál sedel ventilů. In: Proceedings of METAL 2005 - 14th Int. Conf. Metalurgy and Materials, Ostrava : Tanger, Ltd., 2005, Paper no.2, p.1-5, ISBN 80-7849-972-5.

[4] SKRBEK, B. (2006). Slitiny železa na výfuková potrubí spalovacích motoru - trendy. In: Proceedings of METAL 2006 - 15th Int. Conf. Metalurgy and Materials, Ostrava: Tanger, Ltd.,. Paper 114. pp.5, ISBN 80-86840-18-2.

[5] SKRBEK, B. (2006). NDT diagnostika strukturních změn austenitických ventilových ocelí. In: Proceedings of Provozní degradace austenitických ventilových ocelí, Liberec, TU SF KMT, p. 58-62, ISBN 80-7372-113-9.

[6] DOČEKAL, J., SKRBEK, B. (2007). Non-destructive structuroscopy of brake and clech disks. In: Proceedings of 15 World Wheelset Congress, Prague Congress Centre, September 23-27, [CD ROM].

[7] ANDRŠOVÁ, Z. (2014). Nedestruktivní strukturoskopie izotermicky kalených litin. Ph.D. Thesis, TU of Liberec,

[8] PREMUS, M. (2015). Technologické zkoušky litinových brzdových kotoučů. M.Sc. Thesis, VŠB-TU Ostrava,

[9] ANDRŠOVÁ, Z., SKRBEK, B. (2012). The use of magnetic and ultrasonic structuroscopy for inspection of ADI/AGI castings. (2012). Sample Journal Manufacturing Technology, Volume 12, p. 93-97, ISSN 1213-2489.

[10]NOVA, I., MACHUTA, J. (2014). Monitoring Methods the Properties and Structure of Grey Iron Castings. Sample Journal, Manufacturing Technology, Volume 14, p. 223-228, ISSN 1213-2489.

[11]ULEWICZ, R. (2014). Practical Application of Quality Tools in the Cast Iron Foundry. Sample Journal, Manufacturing Technology, Volume 14, p. 104-111, ISSN 1213-2489. 